\title{
Assessment of the influence of social factors on reproduction of personnel potential in agriculture of Russia
}

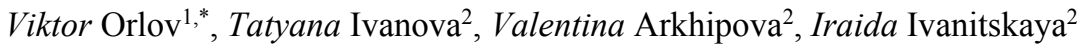 \\ ${ }^{1}$ Moscow State University of Civil Engineering, Yaroslavskoye shosse, 26, Moscow, 129337, Russia \\ ${ }^{2}$ Chuvash State University named I.N. Ulyanov, Moskovsky prospect, 15, Cheboksary city, 428015, \\ Russia
}

\begin{abstract}
Based on the results of the PEST-analysis and methodological tools for determining the motives for the potential turnover of staff from agriculture, the dependence of the reproduction of personnel potential on social factors was revealed. Using the method of index analysis, the article developed a method for calculating the integral indicator of changes in social conditions in agriculture. Further, using the tools of mathematical modeling, its effect on the reproduction of personnel potential in the industry was proved.
\end{abstract}

\section{Introduction}

At the beginning of the XXI century, new realities of the economy revealed an urgent need for modern technologies to study the process of reproduction of personnel potential, both in the national economy as a whole and in agriculture, because the pre-reform methods are hopelessly outdated [1]. This article will assess the impact of social factors on the reproduction of personnel potential in agriculture of the Russian Federation.

During the PEST-analysis (the experts were specialists from the Ministry of Agriculture of the Chuvash Republic), it was found that in the group of «social factors» the maximum influence was made by such factors as: the development of rural social infrastructure -0.78 points and the unemployment rate in the village - 0.59 points. Developed and approved by the author, methodological tools for determining the motives for potential staff turnover from agriculture also confirmed the dependence of the reproduction of personnel potential on social factors. The specificity of the process of reproduction of personnel potential predetermined the need for organizing a sociological survey in four stages (the first study was conducted in 2002-2003, the second - in 2015-2016): graduates of general rural schools, students of higher and secondary agricultural educational institutions, employees of agricultural organizations, unemployed people in rural areas [2]. So, students, in the middle of the reasons for their reluctance to work in agriculture, put him in fourth place they are not satisfied with the social and living conditions in rural areas [3].

\footnotetext{
*Corresponding author: orlovvn@mgsu.ru
} 
At the initial stage of the assessment, a sample of the most significant criteria is formed for calculating the influence of social factors on the reproduction rate of personnel potential in agriculture (details in the author's monograph [2]). In enlarged form, it includes a wide variety of indicators, but to simplify the calculations, twelve (available, not least, freely available on the Rosstat website) (Table 1) will be used (table 1) that have the greatest impact on the reproduction rate of personnel potential (identified using correlation regression and PEST analyzes), which will be reduced

to the index value (in \% of the previous year) so that they can be taken into account when calculating the integral indicator.

Table 1. The main social indicators characterizing the possibility of reproducing personnel potential in the agriculture of the Russian Federation in 2010-2015.

\begin{tabular}{|l|c|c|c|c|c|c|}
\hline Indicators & $2010 \mathrm{y}$. & $2011 \mathrm{y}$. & $2012 \mathrm{y}$. & $2013 \mathrm{y}$. & $2014 \mathrm{y}$. & $2015 \mathrm{y}$ \\
\hline $\begin{array}{l}\text { Rural population, million people } \\
\text { (January 1) }\end{array}$ & 37587.2 & 37444.2 & 37314.4 & 37228.8 & 37118.2 & 37985.1 \\
\hline $\begin{array}{l}\text { The average monthly nominal } \\
\text { accrued wages of workers in } \\
\text { agriculture, rub. }\end{array}$ & 10668 & 12464 & 14129 & 15724 & 17724 & 19455 \\
\hline $\begin{array}{l}\text { Unemployment rate of rural } \\
\text { population,\% }\end{array}$ & 9.8 & 9.4 & 9.4 & 8.3 & 7.7 & 7.9 \\
\hline $\begin{array}{l}\text { Commissioning in the countryside: } \\
\text { residential buildings, mln. m total } \\
\text { area }\end{array}$ & 14.7 & 15.5 & 15.7 & 17.5 & 21.8 & 23.4 \\
\hline $\begin{array}{c}\text { general educational institutions, } \\
\text { thousand student places }\end{array}$ & 20.2 & 21.9 & 14.4 & 24.2 & 16.8 & 24.0 \\
\hline $\begin{array}{c}\text { preschool institutions, thousand } \\
\text { places } \\
\text { hospitals, thousand beds }\end{array}$ & 3.5 & 6.4 & 6.8 & 15.6 & 26.3 & 31.4 \\
\hline $\begin{array}{c}\text { outpatient clinics, thousand visits } \\
\text { per shift }\end{array}$ & 2.6 & 5.9 & 6.0 & 5.1 & 8.4 & 9.6 \\
\hline $\begin{array}{c}\text { Commissioning of utility facilities: } \\
\text { water supply networks, km }\end{array}$ & 1522.0 & 1799.7 & 1368.0 & 1661.5 & 1750.4 & 1868.6 \\
\hline $\begin{array}{l}\text { gas networks, thousand km } \\
\text { power lines for electrification, }\end{array}$ & 6.3 & 8.2 & 13.8 & 14.5 & 17.3 & 12.1 \\
\hline thousand km & 699.2 & 715.1 & 722.6 & 574.9 & 627.5 & 583.1 \\
\hline highways, km & 11.6 & 12.6 & 9.1 & 8.8 & 9.1 \\
\hline
\end{tabular}

Note: Compiled by the author according to [4].

Unfortunately, the collection "Agriculture, hunting and hunting, forestry in Russia» since 2015. It is published once every two years; therefore, the authors do not have data for calculating the influence of social factors on the reproduction of personnel potential in the agriculture of the Russian Federation for a more distant future.

\section{Study materials and methods}

The method of index analysis allows you to aggregate a wide range of quantitative indicators of reproduction in agriculture, having different units of measurement and not 
comparable among themselves without standardization of values. So far, the index method has not been widely adopted in the reproduction management system in agriculture and "... was used only in assessing social and labor relations, labor potential of the regions and monitoring the mechanism of remunerating agricultural labor" $[5,6,7,8]$.

On the basis of table 1, table 2 is compiled, reflecting the index values $f$ social indicators affecting the reproduction of personnel potential in the agriculture of the Russian Federation in 2011-2015.

Table 2. Dynamics of changes in social indicators affecting the reproduction of personnel potential in the agriculture of the Russian Federation in 2011-2015.

\begin{tabular}{|c|c|c|c|c|c|}
\hline Indicators & $2011 \mathrm{y}$. & $2012 y$. & $2013 y$. & $2014 y$. & $2015 \mathrm{y}$. \\
\hline $\begin{array}{l}\text { Index of changes in the number of rural population } \\
\text { (January 1) (in\% to the previous year) }\end{array}$ & 99.6 & 99.7 & 99.8 & 99.7 & 102.3 \\
\hline $\begin{array}{l}\text { Index of changes in the average monthly nominal } \\
\text { accrued wages of workers in agriculture (in } \% \text { to the }\end{array}$ & 114.4 & 111.8 & 110.1 & 111.3 & 108.9 \\
\hline $\begin{array}{l}\text { Index of changes in the unemployment rate of the } \\
\text { rural population (as } \% \text { of the previous year) }\end{array}$ & 95.9 & 100 & 88.3 & 92.8 & 102.6 \\
\hline Integral indicator of commissioning of social & 118.9 & 77.8 & 108.4 & 115.3 & 85.4 \\
\hline Integral indicator of commissioning of public & 104.2 & 101.2 & 86.7 & 106.3 & 87.2 \\
\hline $\begin{array}{l}\text { Integral indicator of changes in social conditions in } \\
\text { agriculture, points }\end{array}$ & 111.3 & 91.5 & 100.4 & 110.1 & 90.3 \\
\hline $\begin{array}{l}\text { Index of change in the indicator of reproduction of } \\
\text { personnel potential in agriculture* } \\
\text { (in } \% \text { to the previous year), } \mathrm{I}_{\text {reprod.p.p. in agric. }}\end{array}$ & 104.5 & 91.3 & 92.7 & 117.1 & 103.2 \\
\hline
\end{tabular}

Note: Compiled by the author

*Designed in accordance with the author's methodology, considered in [9].

The integral indicator of the introduction of social infrastructure facilities in rural areas of the Russian Federation was calculated using formula 1, based on the index values of five factors (Table 2): commissioning in rural areas of residential buildings, educational institutions, pre-school institutions, hospitals, and outpatient clinics.

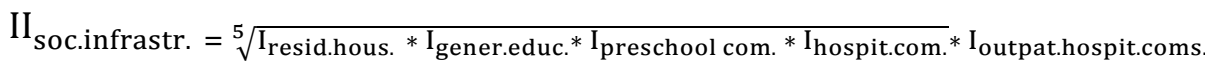

Where $\mathrm{II}_{\text {soc.infrastr. - integral indicator of the introduction of social infrastructure in }}$ rural areas, points;

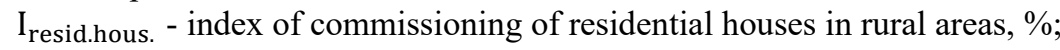

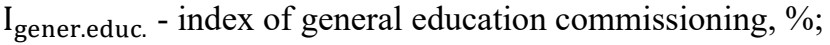

I preschool com. - index of preschool commissioning, \%;

I hospit.com. - index of hospital commissioning, \%;

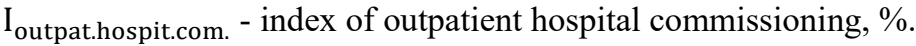

All indices were calculated in\% against the previous year.

The integral indicator of commissioning utility facilities in rural areas was calculated using formula 2, based on the index values of four factors (Table 2): the commissioning of water supply networks, gas networks, power lines for electrification, and highways.

$$
\mathrm{II}_{\text {com.util. }}=\sqrt[4]{\mathrm{I}_{\text {wat.sup.networs }} * \mathrm{I}_{\text {gas networks }} * \mathrm{I}_{\text {line electrif. }} * \mathrm{I}_{\text {road commis }}}
$$

Where $\mathrm{II}_{\text {com.util. }}$ - integral indicator of commissioning of public utilities, points;

$\mathrm{I}_{\text {wat.sup.networs }}$ - index of commissioning of water supply networks, \% 
$I_{\text {gas networks }}$ - index of commissioning of gas networks, \%;

$\mathrm{I}_{\text {line electrif. }}$ - index of power line commissioning for electrification, $\%$;

$\mathrm{I}_{\text {road commis }}$ - index of road commissioning, $\%$.

To calculate the integral indicator of changes in social conditions in agriculture, the proposed formula 3 .

$$
\mathrm{II}_{\text {soc.cond.in agric. }}=\frac{\left(\sqrt[3]{\mathrm{I}_{\text {numb.popul. }} \mathrm{I}_{\text {wages }} * \mathrm{I}_{\text {unempl.rate }}}\right)+\mathrm{II}_{\text {soc.infrastr. }}+\mathrm{II}_{\text {com.util. }}}{3}
$$

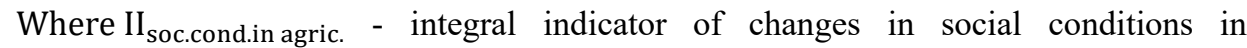
agriculture, points;

$\mathrm{I}_{\text {numb.popul. }}$ index of changes in the number of rural population, $\%$;

$\mathrm{I}_{\text {wages }}$ - index of changes in the average monthly nominal accrued wages of workers in agriculture, $\%$;

$\mathrm{I}_{\text {unempl.rate }}$ - index of changes in the unemployment rate of the rural population, $\%$.

\section{Results}

At the next stage, with a view to further detailing the problem under study, it is proposed to use mathematical modeling tools to study the influence of social conditions emerging in the


reproduction of personnel potential ( $\mathrm{I}_{\text {reprod.p.p. in agric. }}$ ). According to publications, mathematical modeling is actively used for research in complex technical processes [10$24]$, in economics $[9,25,26]$, in medicine $[27,28]$.

In this paper, to study the process of reproduction of personnel potential in agriculture, we used a multifactorial correlation analysis. Based on the method of index indicators, 6 indicators are presented, presented in Table 2 and their statistics from 2011 to 2015 . At the first stage, the interfactorial correlation was analyzed, which showed high correlation between the fourth and sixth factors in Table 2. The indicators were used to build the multifactor model: 1 . The index of the change in the number of the rural population; 2 . The index of changes in the average monthly nominal accrued wages of workers in agriculture; 3 . Index of changes in the unemployment rate of the rural population; 4. The integral indicator of the commissioning of social infrastructure facilities; 5. Integral indicator of commissioning of public utilities. We introduce the notation of these factors, respectively. Based on the theory of multifactor regression, a multivariate model was calculated:

$$
Y=3,6232 \cdot X_{1}-4,4615 \cdot X_{2}+0,6321 \cdot X_{3}+0,5888 \cdot X_{4}+1,1841 \cdot X_{5}
$$

Where $\mathrm{Y}$ - is the index of change in the indicator of reproduction of personnel potential in agriculture. The quality indicator of the constructed model $\mathrm{R}^{2}-$ is the coefficient of multiple determination,

$\mathrm{R}^{2}=0.9999$. The significance of the model was confirmed using the Fisher statistical test at a significance level of $\alpha=0,05$ and Fcritical=4,28; Fobsev=37996,2.

\section{Discussion}

The structure of the multifactor model implicitly indicates the connection of the third factor with the fourth and fifth. Significant factors affecting the index of changes in the indicator of the reproduction of personnel potential are the index of population change and the index of changes in wages. The latter is implicitly reflected in the integrated indicators of the input of social infrastructure and the introduction of public utilities. To obtain a point 
forecast based on the constructed multi-factor model, the point forecast was calculated for each factor of the multi-factor model. The information of each factor was considered as a time series. The additive structure of time series and the technology of their processing based on the moving average method were chosen. The model quality index is calculated on the basis of analysis of variance [29]. Characteristics of the models are shown in table 3.

Table 3. Characteristics of mathematical models.

\begin{tabular}{|l|l|l|l|l|}
\hline $\begin{array}{l}\text { Factor } \\
\mathrm{X}_{\mathrm{i}}\end{array}$ & Modelstructure & $\begin{array}{l}\text { The structure of the trend } \\
\text { components } \mathrm{T}\end{array}$ & $\begin{array}{l}\text { Modelquality } \\
\text { scoreR }\end{array}$ & $\begin{array}{l}\text { Spot forecast for } \\
\text { factor a } \mathrm{X}_{\mathrm{i}}\end{array}$ \\
\hline $\mathrm{X}_{1}$ & $\mathrm{X}_{1}=\mathrm{S}+\mathrm{T}+\mathrm{E}$ & $\mathrm{T}=98,5275+0,54 \mathrm{t}$ & $\mathrm{R}^{2}=0.6988$ & $\mathrm{X}_{1}=101.405$ \\
\hline $\mathrm{X}_{2}$ & $\mathrm{X}_{2}=\mathrm{S}+\mathrm{T}+\mathrm{E}$ & $\mathrm{T}=114,111-\mathrm{t}$ & $\mathrm{R}^{2}=0.9991$ & $\mathrm{X}_{2}=197.1667$ \\
\hline $\mathrm{X}_{3}$ & $\mathrm{X}_{3}=\mathrm{S}+\mathrm{T}+\mathrm{E}$ & $\mathrm{T}=95,2167-0,0833 \mathrm{t}$ & $\mathrm{R}^{2}=0.9021$ & $\mathrm{X}_{3}=89.95$ \\
\hline $\mathrm{X}_{4}$ & $\mathrm{X}_{4}=\mathrm{S}+\mathrm{T}+\mathrm{E}$ & $\mathrm{T}=100,9889+0,667 \mathrm{t}$ & $\mathrm{R}^{2}=0.9642$ & $\mathrm{X}_{4}=114.133$ \\
\hline $\mathrm{X}_{5}$ & $\mathrm{X}_{5}=\mathrm{S}+\mathrm{T}+\mathrm{E}$ & $\mathrm{T}=106,8438-2,89 \mathrm{t}$ & $\mathrm{R}^{2}=0.6417$ & $\mathrm{X}_{5}=94.7725$ \\
\hline
\end{tabular}

Geometric interpretation of models for factors is presented in Figures 1-5, respectively.

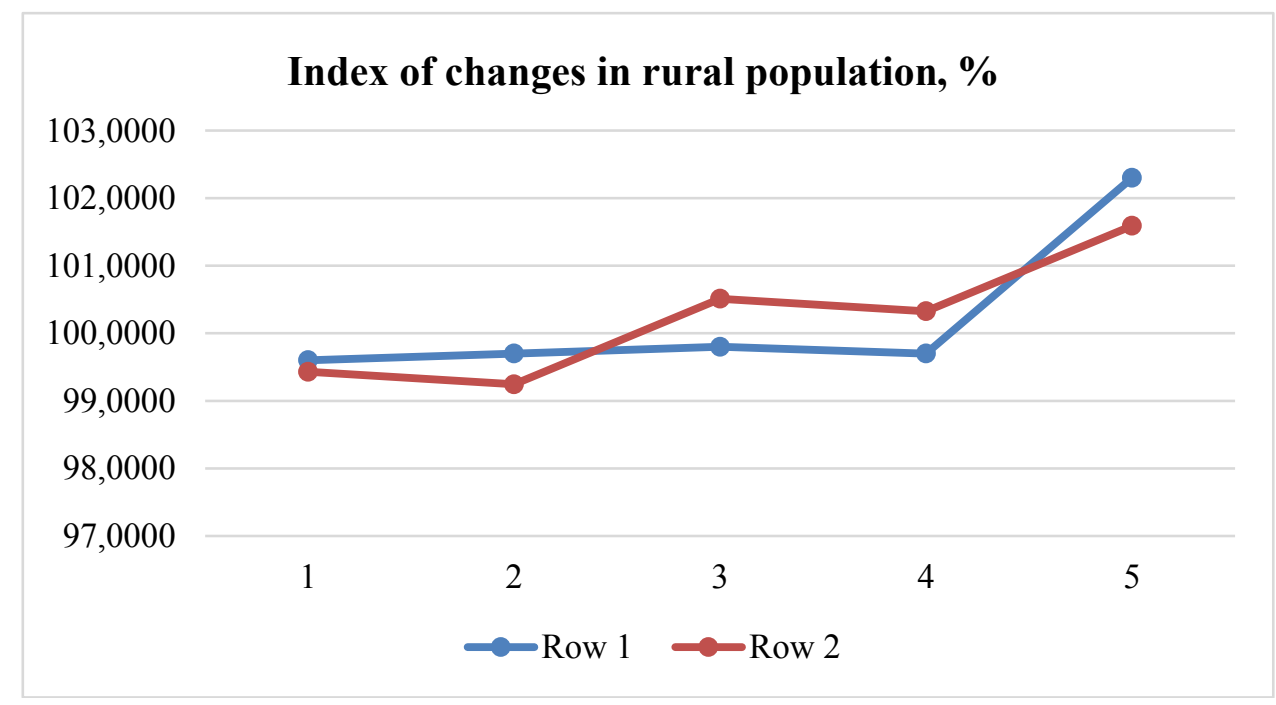

Fig. 1. Row 1 - initial information of the factor $X_{1}$, row 2 is the geometric interpretation of the mathematical model. 




Fig. 2. Row 1 - initial information of the factor $X_{2}$, row 2 is the geometric interpretation of the mathematical model.



Fig. 3. Row 1 - initial information of the factor $\mathrm{X}_{3}$, row 2 is the geometric interpretation of the mathematical model. 


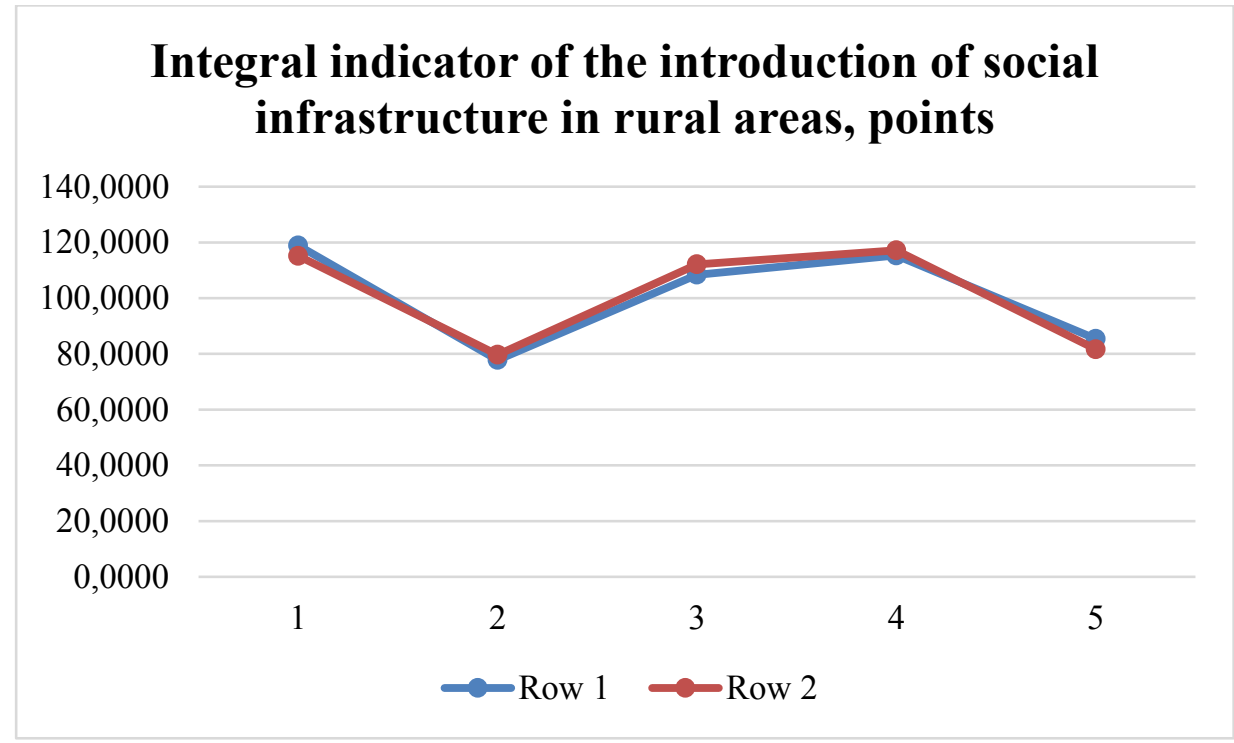

Fig. 4. Row 1 - initial information of the factor $\mathrm{X}_{4}$, row 2 is the geometric interpretation of the mathematical model.

\section{Integral indicator of commissioning of public utilities, points}



Fig. 5. Row 1 - initial information of the factor $\mathrm{X}_{5}$, row 2 is the geometric interpretation of the mathematical model.

Based on the obtained point forecasts of factors, we can calculate a point forecast for the multifactor model Yforecast $=125,5311$. Then, based on the analysis of variance [29], we obtain the confidence interval of the predicted value of the multifactor model.

$$
125,5185 \leq \text { Y forecast } \leq 125,5437 \text {. }
$$

\section{Conclusion}

Summing up, it should be noted that the reproduction of personnel potential in agriculture is determined by what conditions, how and where, it is consumed and used. Based on the constructed mathematical models, it is proved that the significant social factors affecting 
the index of changes in the indicator of reproduction of the personnel potential in the industry are the index of changes in the number of rural population and the index of changes in wages. The latter, implicitly, is reflected in the integrated indicators of the commissioning of social infrastructure and public utilities.

So, when changing the index of the number of the rural population of the Russian Federation in 2015: - by $102.3 \%$, wages - by $108.9 \%$, indicator of commissioning of social infrastructure facilities - by $85.4 \%$, utilities - by $87.2 \%$, the index of change in the reproduction of personnel potential was $103.2 \%$. In 2014 the index of change in the integral indicator of the commissioning of social infrastructure was $106.3 \%$, while the index of reproduction of the personnel potential in agriculture changed by $117.1 \%$. That is, there is a relationship between the level of social infrastructure development and the rate of reproduction of personnel potential in the industry: the faster the first indicator grows, the higher the second one and, vice versa. This proves that the proposed method makes it possible to objectively evaluate the influence of social factors on the reproduction of personnel potential in agriculture of the Russian Federation and is one of the reasons for legislative and executive authorities in developing socio-economic projects and programs.

\section{References}

1. T.V. Ivanova, Personnel potential of agricultural enterprises: the formation and using (Publishing house Chuvash University, Cheboksary, 2006)

2. T.V. Ivanova, System management of the reproduction of personnel potential in agriculture (Publishing house Chuvash University, Cheboksary, 2018)

3. T.V. Ivanova, A.A. Ivanova, Strategies of modern scientific development: mater. XXIII Intern. scientific-practical. conf. (Create Space, North Charleston, 2017)

4. http: // www: gks.ru

5. L.M. Borisova, N.V. Ionikan, V.A. Kolupaeva, V.S. Rakovskaya, News of Tomsk Polytechnic University 6, 32-36 (2011)

6. L. Bertalanffy, General systems theory: acritical review (Progress, Moscow, 1969)

7. Yu.A. Petrov, D.K. Stozhko, Agrarian Bulletin of the Urals 7(149), 106-113 (2016)

8. N.I. Proca, M.A. Fokin, Bulletin of Agrarian Science 6(69), 158-165 (2017)

9. T.V. Ivanova, V.N. Orlov, G.N. Sokolova, Economics of Agriculture of Russia, 747-53 (2017)

10. A.A. Samodurov, V.M. Chudnovsky, Dokl. AN BSSR 1(29), 9-10 (1985)

11. M. Ablowitz, A. Romani, H. Segur, J. Mat. Phys. 9(21), 715-721, 1006-1015 (1980)

12. M. Ablowitz, A. Romani, H. Segur, Lett. alNuowoCim. 9(23), 333-338 (1978)

13. A. Chichurin, Mathematical Notes 18, 701-715 (2017)

14. A. Chichurin, H. Shvychkina, Mathematical Biosciences 278, 30-36 (2016)

15. A. Chichurin, E. Ovsiyuk, V. Red'kov, Computers and Mathematics with Applications 75, 1550-1565 (2018)

16. V.B. Taranchuk, Scientific sheets of the Belgorod state University 16(265)43, 148-159 (2017)

17. V.B. Taranchuk, M.A. Zhuravkov, Vestnik Belarusian state University 3(1), 97-107 (2016)

18. V.B. Taranchuk, MATEC: Web of Conferences 9, 04059(251) (2019)

19. O.A. Kovalchuk, Procedia Engineering 2(153), 304-309 (2016) 
20. V.N. Orlov, O.A. Kovalchuk, Materials Science and Engineering:IOP Conference Series 365 (2018) doi:10.1088/1757-899X/365/4/042045

21. V.N. Orlov, O.A. Kovalchuk, E.P. Linnik, I.I. Linnik, Vestn. Mosk. Gos. Tekh. Univ.im. N.E. Baumana, Estestv. Nauki 4, 24-35 (2018) DOI: 10.18698/1812-33682018-4-24-35

22. V.N. Orlov, O.A. Kovalchuk, E.P. Detina, MATEC Web of Conferences 251 (2018) https://doi.org/10.1051/matecconf/201825104012

23. V.N. Orlov, E.P. Detina, MATEC Web of Conferences (2018) doi:https://doi.org/10.1051/matecconf/201825104041

24. V.N. Orlov, O.A. Kovalchuk, Materials Science and Engineering: IOP Conf. Series 456, 012122 (2018) doi:10.1088/1757-899X/456/1/012122

25. V.N. Orlov, T.V. Ivanova, Economics of agricultural and processing enterprises 12, 73-77 (2016)

26. V.N. Orlov, T.V. Ivanova, AIC: Economics and Management 10, 67-76 (2016)

27. V.N. Orlov, Disease prevention and health promotion 5, 44-47 (2007)

28. V.N. Orlov, Kazan Medical Journal 6(90), 889-892 (2009)

29. V.N. Orlov, Bulletin of the RSSU (Branch of the city of Cheboksary) 1(30), 128-129 (2014) 